\title{
The Support of the Family toward Children with Autism Spectrum Disorder \\ by Nyoman Anita Damayanti
}

Submission date: 16-Apr-2019 09:41AM (UTC+0800)

Submission ID: 1113261333

File name: of_The_Family_toward_Children_with_Autism_Spectrum_Disorder.docx (127.08K)

Word count: 3002

Character count: 17189 


\title{
The Support of the Family toward Children with Autism Spectrum Disorder
}

\author{
Siti Maemonah'. Hamidah2, Nyoman Anita Damayanti3, Enung Mardiyana Hidayar', Aida Novitasari4, \\ Qorry Aina5, Wina Tryas Fatima \\ 'Doctoral Program of Public Health, Faculty of Public Health, 'Faculty of sychology, 'Faculty of Public \\ Health, Universitas Airlangga, Mulyorejo, Surabaya, Indonesia; "Lecturer, ${ }^{5}$ Student, Politeknik Kesehatan \\ Kementerian Kesehatan, Surabaya
}

\begin{abstract}
Autism Spectrnm Disorder (ASD) cases have increased worldwide. The family supports are crucial for the development of children with ASD. This study aimed to identify the support from the family toward children with ASD. A descriptive study was conducted involving 14 family members who had children with ASD. The variables of this research included informational, judgmental, instrumental and emotional support. The informational $(92.8 \%)$, emotional $(85.7 \%)$, judgmental $(57.1 \%)$ and instrnmental $(85.7 \%)$ supports from families to children with ASD were good. Future research should undertake the study with a larger sample and examine them using different variables.
\end{abstract}

Keywords: autism spectrum disorder family support

\section{INTRODUCTION}

It is predicted worldwide that I out of 160 children suffers from Autism Spectrum Disorder (ASD)'. This prediction represents the average number and prevalence reported, as it has varied substantially across the total relevant research. A number of corresponding research studies have reported an ultimately higher number ${ }^{2}$. Based on the studies of epidemiology conducted in the last 50 years, the prevalence of ASD appears to have soared globally. Over $1.5 \%$ of children were identified with ASD based on an 3 tensive search in 11 different communities across the United States (Arizona, Arkansas, Colorado, Georgia, Maryland, Missouri, New Jersey, North Carolina, South Carolina, Utah, and Wisconsin) in $2012^{3}$.

There is no official survey on the number of children with ASD in Indonesia. However, in 2013, the

Corresponding Author:

$4^{\text {ti }}$ Maemonah

Doctoral Program of Public Health,

Faculty of Public Health, Universitas Airlangga,

Mulyorejo, Surabaya, Indonesia

Email: sitimaemonah71@yahoo.com
Indonesian Ministry of Health has presumed that the number of children with autism was over 112 thousand, with an age interval of 5 to 19 years old. This number was generated based on the calculation of autism prevalence being over 1.68 per 1,000 children under 15 years of age ${ }^{4}$ With the overall amount of children aged 5-19 years in Indonesia being over 66 million according to Indonesia's Central Bureau of Statistic in 2010, it generated the aforementioned number of 112 thousand In 2015 , it was expected that there were 12,000 children with autism or 134.000 persons on the autism spectrum in Indonesia ${ }^{4}$.

Based on the criteria of the Diagnostic Statistical Manual Ill-R of the World Health Organisation (DSM III-R WHO) in 2009, there were no less than 4.000 citizens of Surabaya city identified as suffering from autism $^{5}$. In one of the Schools for Exceptional Children in the city of Surabaya, Galuh Handayani Elementary School in the 2016/2017, it was found that there were 27 students who had been considered as having autism.

Children with ASD require normal treatment, guidance, and individual orientation in order to learn how to socialize and play with their friends. This is so then they can adhere to acceptable age-appropriate behavior in order to not block their development. The growth of 
children is influenced by their surrounding environment, particularly their family, school and the society where they live through socialization ${ }^{6}$. The life of children is significantly determined by the support of their family. If the supports are good, their growth and development will be relatively stable. On the other hand, if the support is non-existent, their children will experience significant retardation which may impair their mental".

The support of the family is an integral part of social support which categorized into four types. including informational, judgemental, instrumental and emotional", Informational support can be instrumented in the form of the family seeking information regarding the child's health and training the child to study in their daily life. Judgmental support can be realized in the form of the family giving the child the opportunity to do the activities that they find joyful. Instrumental support can be delivered in the form of the family to provide transportation and medication fees, with the family preparing for all of their daily needs. Emotional support can be realized through the family motivating the children to communicate with their friends and caring for their child with affections.

Positive support from their family may help to recover the social function of children with autism9. On the contrary, negative support from their family will result in unmanageable children who are unable to be properly orientated, educated and empowered which may result in unwanted behaviors. Unsupported children with autism will also experience a major drawback in achieving their tasks.

This study aimed to identify the support from the family toward children with ASD in Galuh Handayani Elementary School, Surabaya.

\section{METHODS}

This study was descriptive research, focused on describing the familial support of children with ASD in Galub Handayani Elementary School, Surabaya. The process of the data collection was through observations of families with children with ASD. The participants in this research were parents whose children had ASD in grades $1-3$ in the academic term of 201712018. Fourteen parents of 14 children were involved. The variables of this research included informational, judgmental, instrumental and emotional support.
The instrument of the data collection was a questionnaire with 24 different statements consisting of 6 statements for informational support, 7 statements for emotional support, 5 statements for judgmental support and 6 statements for instrumental support. The assessment method used a Likert scale modified through the following categories: "always" scored 3, "often" scored 2, and "sometimes" scored 1 and "never" scored 0 . Later on, the accumulative score was converted into a percentage and interpreted as follows: good $76-100 \%$, enough $56-75 \%$ and deficient $<56 \%{ }^{10}$.

The data was processed, tabulated, and analyzed in a descriptive manner. The data was served in the form of frequency distribution table and narrative in order to describe the visualization of familial supports to the chHdren with ASD.

\section{RESULTS}

Table 1: Demographic data of family of children WithASD

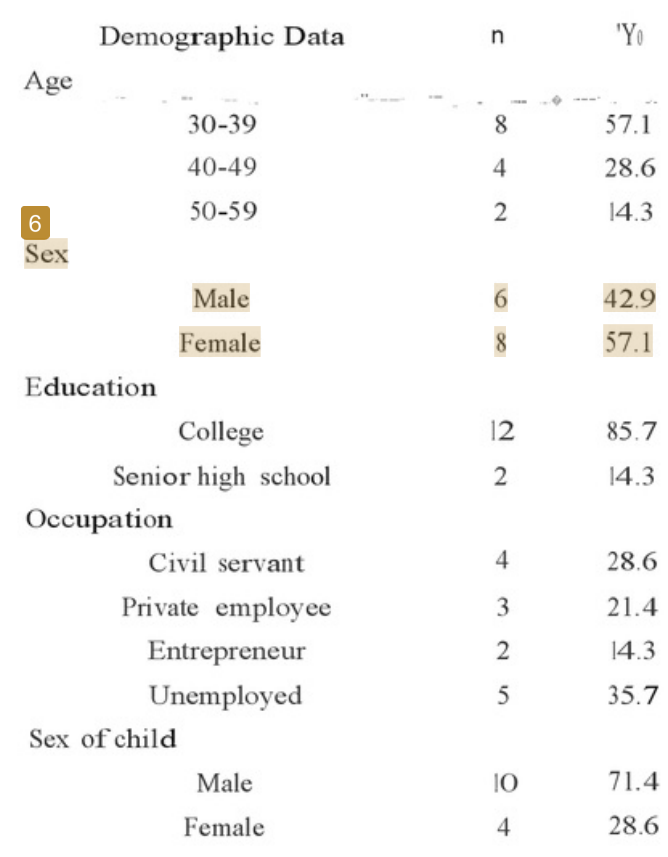

As described in Table 1 , most of the respondents were aged 30-39 years old (57.1\%). The respondents' sexes were mostly female but almost equal to the male with $57.1 \%$ and $42.9 \%$ respectively. Almost all the respondents graduated from college $(85.7 \%)$. Also, 
88 Indian Journal of Public Health Research \& Development. November 2018, Vol.9. No. II

unemployed become the most occupation with $35.7 \%$.

Meanwhile, the sex of the children was mostly male $(71.4 \%)$.

Table 2: Family support of children with ASD

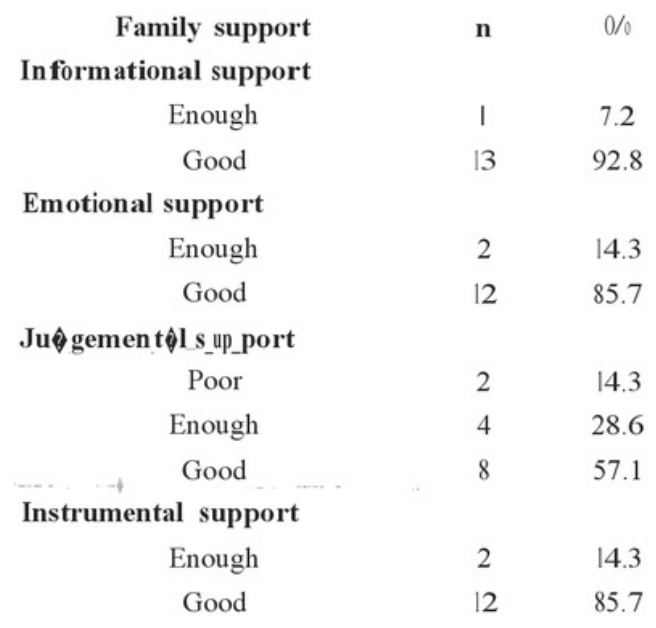

Based on Table 2, most of the family provided good informational, emotional, and instrumental supports to their children with $92.8 \%, 85.7 \%$, and $85.7 \%$ respectively. However, in the judgemental support, the good support was still dominant $(57.1 \%)$, but there was $14.3 \%$ poor support which absent in the other three kinds of supports.

\section{DISCUSSION}

1. Informational Support: Informational support is comprised of advice, orientation, suggestion or judgment over how an individual performs something". One of the support given by the family for the growth of the child is to deliver guidance in them developing proper behavior".

In this research, it was discovered that almost all of the children with ASD (93\%) were equipped with the favorable informational support. TIle support given by their parents towards the growth of the children with ASD has been visualized in the form of proper behavioral guidance through appropriate orientation and the advice given to them. This was realized by the family by seeking information related to the child's health, educating the child and training them to deal with their daily activities such as learning how to eat and dress themselves. This result is in line with research which shows that informational support was in the high category $(52.1 \%)^{13}$. The particular research identified the connection between familial support and the behavior of children with autism. Out of 23 children with autism with low informational support, $60.9 \%$ behaved hyperactively".

Social and informational support, which were both provided by the parental support cluster, were the most frequently reported necessities according to the parents of adolescents with growth disorders ${ }^{4}$. This informational support includes the search for information regarding the child's issue by the parents so then it can be delivered to the right person. This also allows them to give advice so then the impact gained by the parents means that they are able to control the negative behavior of their children.

The family has to deliver it by simplifying sentences that are understandable and not confuse them. Because communication disorders are commonly experienced by children with autism". The informational support can also be delivered by giving them the right advice on the subject of their language so then the children favorably understand the advice given to them. This particular pattern implies that the support delivered by the parents guides them to the right behavior through orientation and the advice addressed to them ${ }^{6}$.

2. Emotional Support: Emotional support consisted of various expressive forms such as attention, empathy and the feeling of concern towards somebody". The form of emotional support was giving attention to them, such as greeting them, asking them about their condition, approaching and paying them a visit when the person is in need, asking about the condition of someone's feeling, listening to their grievances and also understanding and accepting the condition of someone as they are.

It was discovered that almost the entire children with ASD (86\%) were provided with good emotional support This result is can be observed from the approval of the family including the parents. The approval can be contextualized in the form of attention given by the parents to their ASD affected children including by prioritizing 
Indian Journal of Public Healtk Research \& Development, November 2018, Vol 9, No. II 89 the preparation of food for the children with ASD instead of their siblings who are non-sufferer to ASD and motivate the children upon lack of appetite. This result is against research which showed that the majority $(56.25 \%)$ the emotional support given to the children with autism was situated in the low category"

The emotional support can be identified by how far the attention is given by each parent boosts the confidence of the children, so the children do not feel inferior while performing social interactions and the family accept the children as they are". The approval was in the form of more attention and affection toward them in comparison to other children. The emotional support would cause the supported recipient to feel comfortable due to the assistance that is apparent in the form of motivation, personal tenderness, and love ${ }^{11}$. These emotions are what the parents perform on a daily basis, by assisting their children during home studying and asking them about their feelings.

3. Judgmental Support: Judgmental support influences the receiving individual to develop feelings of self-appreciation, confidence, and worthiness. The distribution ofjudgmental support from the parents can leverage the confidence within the children so that then children would not feel inferior upon staying outside of their home. It was identified that the majority of children with ASD $(57 \%)$ in Galuh Handayani Elementary School are provided with good judgmental support. This result is in line with a study which pointed out that the majority $(68.75 \%)$ ofjudgmental support from parents to their children with autism was in the high category!'.

The parents are entitled to taking on full responsibility for the child's social progress ${ }^{17}$. The parents should start trusting their children and not limiting them in performing various things such as dining, showering, and dressing. These particular treats are aimed to enhancing their self-confidence So then they are capable of undertaking bigger tasks. Judgmental support can also be performed through attention and motivating judgment, which may support them in their jobs and tasks, achievements and attitude. As an example, the parents would allow them to participate in

activities that the children find joyful, including swimming and horse-riding, and embarking to school by themselves ${ }^{6}$. This judgmental support will be essential when the children are stressed, such as when the tasks that they endure are bigger than their natural abilities tr.

4. Instrumental Support: Instrumental support is performed by becoming the person whose help is expected when solving the problem that the children are facing steps forward, which is especially related to adapting to life ${ }^{2}$. For examp le, when the parents provide instrumental support in the form of physiological fulfillment, the children will be motivated while studying at school". It was discovered that almost the entire sample population of children with ASD (86\%) in Galuh Handayani Elementary School were provided with favorable instrumental support. This result goes against a study which showed that the majority $(52.1 \%)$ of instrumental support from the parents to their autistic children was situated in the low category':'. The parents have the responsibility to act as an advocate, which means that the parent has the responsibility to support and advocate for their children's best interests uncouditionally". The variety of support which may be given by the parents including providing various types of treatment, encouraging them to exercise as part of a routine, and introducing as early as possible to transportation access and public spaces!". Through the aforementioned support, the aim is to assist in lessening the burden of the child by helping them to undertake particular activities such as studying and performing 8 ir daily habitual activities". This is so then the parents of children with ASD are able to provide proper assistance to their children to help them to develop an adaptive attitude that is acceptable in the wider social sphere. The parents should be trained to use precise coping strategies which gives them the required coping skills to execute this effectively".

\section{CONCLUSION}

The conclusion of this research is that the informational, emotional, judgmental and instrumental supports from families to children with ASD in Galuh Handayani Elementary School were favorable. Futwe research should undertake the study with a larger sample and examine them using different variables. 
90 Indian Journal of Public Health Research \& Development, November 2018, Vo.9. No II

Conflict of Interest: None.

5 thical Clearance: The study passed ethical clearance from the Ethical Committee of the Faculty of Public Health, Universitas Airlangga, Surabaya, Indonesia

Source of Funding: Self-funded

\section{REFERENCES}

I. Elsabbagh M, Divan G, Koh Y-J, Kim YS Kauchali S, Marcin C, et al. Global Prevalence of Autism and Other Pervasive Developmental Disorders. Autism Res [Internet]. 2012 Jun [cited 2018 Sep 5];5(3):160-79. Available from: http:// www.ncbi.nlm.nih.gov/pubmed/22495912

2. Hansen SN, Schendel DE, Pamer ET. Explaining the Increase in the Prevalence of Autism Spectrum Disorders. JAMA Pediatr [Internet]. 2015 Jan 1 [cited 2018 Sep 5];169(1):56. Available from: http://archpedi.jamanetwork com/article. aspx?doi $=10.1001$ jamapediatrics.2014.1893

3. National Center on Birth Defects, and Developmental Disabilities. Community Report on Autism From the Autism and Developmental Disabilities Monitoring Network [Internet]. Atlanta, GA; 2014 [cited 2018 Sep 3]. Available from: wwwcdc.gov/mmwr

4. Budiman E, Santoso E, Afirianto T. Pendeteksi Jenis Autis pada Anak Usia Dini Menggunakan Metode Linear Discriminant Analysis (LDA). J Pengemb Teknol Inf clan Ilmu Komput [Internet]. 2017 [cited 2018 Sep 5];1\{7):583-92. Available from: http://j-ptiik.ub.ac.id

5. Herawati IC. Surabaya Booming Antis. Harian Surya. 2008:

6. Hidayati N. Dukungan Sosial bagi Keluarga Anak Berkebutuhan Khusus. Insan [Internet]. 2011 [cited 2018 Sep 3];13(01): 12-20. Available from: http://journal.unairac.id/download-fullpapersartikel 2-13-1.pdf

7. Hidayat AAA. Pengantar Ilmu Keperawatan Anak. Edisi 2. Jakarta: Salemba Medika; 2005

8. Malecki CK, Demaray MK. What Type of Support Do They Need? Investigating Student Adjustment as Related to Emotional, Informational, Appraisal, and Instrumental Support. Sch Psychol $Q$. 2003;18(3):231-52.

9. Pancawati R. Penerimaan diri dan dukungan orang tua terhadap anak autis. 2013;53(9): 1689-99

10. Arikunto S. Prosedur Penelitian Suatu Pendekatan Praktik. Jakarta: Rineka Cipta; 2006.
11. Sarafino EP, Smith TW. Health psychology : biopsychosocial interactions [Internet]. [cited 2018 Sep 5]. 542 p. Available from: https:// www.wiley.com/en-id/ Health + Psychology: + Biopsychosocial + Interactions, + 8th + Edition-p-9781118425206

12. Hurlock EB. Child Growth and Development United States: Kessinger Publishing, LLC; 2010.

13. Fitri A, Saam Z, Hamidy Y. Pengaruh duk:ungan sosial keluarga terhadap perila:ku anak autis di Kota Pekanbaru. J Ilmu Lingkung [Internet]. 2016 Nov 15 [cited 2018 Sep 3]; 10(1):47-57. Available from: b ttps//ejournal.unri.ac.id/index.php/IlL/ article/view/3576

14. Douma JCH, Dekker MC, Koot HM. Supporting parents of youths with intellectual disabilities and psychopathology. J Intellect Disabil Res [Internet] 2006 Aug | [cited 2018 Sep 3];50(8):570-81. Available from: http://doi.wiley.com/10.1111/ j. 1365-2788.2006.00825.x

15. Wall K. Autism and Early Years Practice [Internet]. I Oliver's Yard, 55 City Road, London EC1Y ISP United Kingdom : SAGE Publications Ltd; 2010 [cited 2018 Sep 5]. Available from: http://sk.sagepub. com/books/autism-and-early-years-practice

16. Inayah F, Sekar DA Bentuk Dukungan Sosial terhadap Anak Autis (Studi Kasus pada Tiga Siswa Autis Di SD Khusus Talenta). Universitas Indonesia; 2014.

17. Mangunsong F. Psikologi dan Pendidikan Anak Berkebutuhan Khusus. Jakarta: LPSP3 UI; 2011.

18. Riany YE, Cuskelly M, Meredith P. Parenting Style and Parent-Child Relationship: A Comparative Study of Indonesian Parents of Children with and without Autism Spectrum Disorder (ASD). J Child Fam Stud [Internet]. 2017 Dec 20 [cited 2018 Sep 5];26(12):3559-71. Available from: http://link springercom/I 0.1007/s1 0826-01 7-0840-3

19. Wilson M, Hamilton D, Whelan T, Pilkington P. A systematic review of factors related to parents' treatment decisions for their children with autism spectrum disorders. Res Autism Spectr Disord [Internet]. 2018;48(July 2017): 17-35. Available from: https://doi.org/10.1016/j rasd.2018.01.004

20. Hall HR, Graff JC. The Relationships Among Adaptive Behaviors of Children with Autism, Family Support, Parenting Stress, and Coping. Issues Compr Pediatr Nurs [Internet]. 2011 Mar 22 [cited 2018 Sep 3];34(1):4-25. Available from; http://vvww.tandfonline.com/doi/full/1 0.3109/014 60862.2011 .555270 


\section{The Support of the Family toward Children with Autism}

\section{Spectrum Disorder 2}

ORIGINALITY REPORT

5

SIMILARITY INDEX
$4 \%$

INTERNET SOURCES
$2 \%$

PUBLICATIONS
$1 \%$

STUDENT PAPERS

PRIMARY SOURCES

1 repository.ubaya.ac.id

Internet Source

2 addm.umn.edu

Internet Source

3 www.ncbi.nlm.nih.gov

Internet Source

4 Submitted to Universitas Airlangga Student Paper

5 Kusnanto Kusnanto, Ni Putu Wulan Purnama

Sari, Harmayetty Harmayetty, Ferry Efendi,

Joko Gunawan. "Self-care model application to

improve self-care agency, self-care activities,

and quality of life in patients with systemic

lupus erythematosus", Journal of Taibah

University Medical Sciences, 2018

Publication 
McStay, Rebecca, David Trembath, and Cheryl

Dissanayake. "Raising a Child with Autism: A

Developmental Perspective on Family

Adaptation", Current Developmental Disorders

Reports, 2015.

Publication

8

Angelo Picardi, Antonella Gigantesco,

Emanuele Tarolla, Vera Stoppioni et al.

"Parental Burden and its Correlates in Families

of Children with Autism Spectrum Disorder: A

Multicentre Study with Two Comparison

Groups", Clinical Practice \& Epidemiology in

Mental Health, 2018

Publication

Exclude quotes 